\title{
Incidence of Benign Theileriosis in Cattle of Puducherry Region, India
}

\author{
N. Devadevi*, K. Rajkumar and P. Vijayalakshmi \\ Department of Veterinary Medicine, Rajiv Gandhi institute of Veterinary Education and \\ Research, Kurumbapet, Puducherry 605009, India \\ *Corresponding author
}

\section{A B S T R A C T}

\begin{tabular}{|l|}
\hline K e y w o r d s \\
Benign \\
Theileriosis, \\
Cattle, \\
Theileria \\
orientalis,
\end{tabular}

\section{Introduction}

The aim of the study was to assess the incidence of theileriosis in cattle of Puducherry region. Bovine Benign Theileriosis is caused by Theileria orientalis and T. segenti/ buffeli found throughout the world and cause mild or asymptomatic disease (Uilenberg 1981). Theileria orientalis is classified into eight genotypes on the basis of diversity in the SSUrRNA and major piroplasm surface protein (MPSP) Kubota $e t$ al. (1996). BBT cause severe form of clinical signs and production losses unless the cattle were affected by stress such as pregnancy, parturition, lactation, inter-current disease and environment factors (Kakuda et al. (2001).

\section{Materials and Methods}

From January to August 2014, a total numbers of 413 cattle were brought to Large Animal Medicine Unit, Teaching Veterinary Clinical Complex, Rajiv Gandhi Institute of Veterinary Education and Research, Puducherry for treatment various medical conditions. One hundred and ten cases with clinical signs suggestive of theileriosis were subjects to clinic-pathological and molecular study. 
Based on the SSUrRNA gene 1098bp for Theileria and MPSP gene-849bp for $T$. Orientalis for PCR/ Blood smear/ Lymph node aspiration smear examination, the result was made and the incidence of Bovine benign theileriosis (Theileria orientalis) was calculated.

\section{Results and Discussion}

The incidence of theileriosis among the cattle presented to Large Animal Medicine Unit, Teaching Veterinary Clinical Complex, Rajiv Gandhi Institute of Veterinary Education and Research, Puducherry was 24.21 per cent $(n=413)$. One hundred and ten cases with clinical signs suggestive of theileriosis, in that a total of $100(90.91 \%)$ cattle were found positive either by peripheral blood smear or lymph node aspiration or PCR, which is in agreements with Keles et al. (2001), Kamau et al. (2011) and $\mathrm{Yu}$ et al. (2011) who reported that theileriosis in cattle was endemic in tropical regions. Whereas Chaisi et al. (2013) and Aktas et al. (2006) reported an incidence of Theileria orientalis was $5.8 \%$ and $7 \%$ in South Africa and Eastern Turkey respectively.

The incidence of the theileriosis was more in female cattle (85\%) when compared with males $(15 \%)$, the increased incidence in female was due to over representation of female cases to TVCC. Gill (1994), Benical et al. (1997) and Kakuda et al., (1998) reported that latent infection of Theileria in females was mainly due to the stress, pregnancy, parturition, lactation undercurrent disease and environment factors.

Cattle in the age group of 3-4 years had highest incidence (34\%) of theileriosis followed by 5-6 years age group (20\%), 7-8 years group (15\%). 9-10 years group (13\%), less than 1 year (9\%) and 1-2 years (9\%) these finding were similar to the reports of
Radostitis et al. (2010) who revealed that young animals were less susceptible than adult cattle.

In the present study, the highest incidence of theileriosis was observed in cross bred jersey (59\%) followed by Holstein Feriesian (23\%), Hallikar (13\%) and non-descript (5\%) which in concurrence with the report of Kachani et al. (1992). Radostitis et al. (2010) opined that the indigenous cattle breeds were less affected than the exotic breeds of cattle.

The incidence of theileriosis was almost equal in stall fed and (50\%) animals and cattle on gazing $(46 \%)$. The present findings were in agreement with that reported by Chae et al. (1996), Choi et al. (1997) and Song and Sang (2003) who reported that higher incidence was noticed in non-gazing cattle, but they were nevertheless lower than in grazing cattle.

\section{References}

Aktas M; Altay K and Dumanli N (2006). A molecular survey of bovine Theileria parasites among apparently healthy cattle and with a note on the distribution of ticks in eastern Turkey. J. Vet. Parasitol, 138: 179-181.

Beniwal R K; Nichani A K; Sharma R D; Radha N R; Suri D and Sarep S (1997). Response in

animals vaccinated with Theileria annulata (Hissar) cell culture vaccine. Trop. Anim. Hlth. Prod, 29: 1095-1135.

Chae J S; Lee J M; Kwon O D; Park J H and Chae K S (1996). Rapid detection of Theileria sergenti by polymerase chain reaction. Korean J. Parasitol,35:111117.

Chaise M E; Janssens M E; Vermeiren L; Oosthuizen M C; Collins N E and Geysen D (2013). Evaluation of realtime pcr test for the detection and discrimination of Theileria species in 
the African Buffalo (Syncerus caffer). PLOS ONE, 10: e75827.

Choi E J; kang S W; Kweon C H; Jeong W S; Yoon Y D and Song H J (1997). Rapid detection of Theileria sergenti by the polymerase chain reaction in Korean cattle. Korean J. Vet. Res,35:111-117.

Kachani M; Oliver R A; Brown C G D; Ouhelli H and Spooner R L (1992). Common and stage specific antigens of T. annulata. Vet. Immun. Immunopath, 34: 221-234.

Kakuda T; Shiki M; Kubota S; Sugimoto C; Brown W C; Kosum C; Nopporn S and Onuma M (1998). Phylogeny of benign Theileria species from cattle in Thailand, China and the U.S.A. based on the major piroplasm surface protein and small subunit ribosomal RNA genes. Int. J. Parasitol, 28:1261-7.

Kamau J; Vos A J D; Playford M; Salim B; Kinyanjul P and Sugimoto C (2011). Emergence of new types of Theileria orientalis in Australian cattle and possible cause of theileriosis outbreaks. Parasites \& Vectors, 4:22.

Keles I; Derger S; Altug N; Karaca M; Kinyanjul P and Akdemir C (2001). Tick born disease in cattle; clinical and haematological findings, diagnosis, treatment, seasonal distribution, breed, sex and age factors and the transmitters of the disease. YYU. Vet. Fak. Derg. 12: 26-32.

Kubota S; Sugumoto C and Onuma M (1996). Population dynamics of Theileria sergenti in persistently infected cattle and vector ticks analyzed by a polymerase chain reaction. Parasitology, 112: 437-442.

Radostits O M; Gay CC; Hynchcliff K W and Constable P D (2010). Veterinary Medicine, A textbook of disease of cattle, sheep, goats, pigs and horses. 10th ed., Book power Saunders, London, New York, pp: 1526-1574.

Song K H and Sang B C (2003). Prevalence of Theileria sergenti infection in Korean native cattle by polymerase chain reaction. Korean J. Parasitol, 41: 141-145.

Uilenberg G (1981). Theileria species of domestic livestock. In: Irvin A.D., Cunninham, M.P., Young, A.S (Eds.), Advances in the control of theileriosis. Martinus NiJhoff Publishers, Hage, the Netherlank, PP-37.

Yu L; Zhang S; Liang W; Jin C; Luo Y; Cao s; Yamagishi J; Nishikwara Y' Kawano S M; Fujisaki K and Xuan X (2011). Epidemiological survey of Theileria parasite infection of cattle in northeast China by allele-specific PCR. J Vet. Med. Sci, 73:1569-1512.

\section{How to cite this article:}

Devadevi, N., K. Rajkumar and P. Vijayalakshmi 2018. Incidence of Benign Theileriosis in Cattle of Puducherry Region, India. Int.J.Curr.Microbiol.App.Sci. 7(06): 2818-2820.

doi: https://doi.org/10.20546/ijcmas.2018.706.330 